\section{Effect of 1-alpha-hydroxycholecalciferol on
magnesium metabolism in
chronic renal failure}

Vitamin $\mathrm{D}$ derivatives and analogues are increasingly being used to treat bone disease in chronic renal failure but their effects on magnesium metabolism have not been fully documented. The use of $1-\alpha-$ hydroxycholecalciferol $\left(1-\alpha-\mathrm{OHD}_{3}\right)$ in chronic renal failure, however, may be associated with a special risk of magnesium intoxication. ${ }^{1}$ This prompted us to review our own data.

\section{Methods and results}

We studied the external balances of calcium and magnesium ${ }^{2}$ in two patients with chronic renal failure and renal bone disease (cases 1 and 2 ; plasma creatinine $480 \mu \mathrm{mol} / 1(5.4 \mathrm{mg} / 100 \mathrm{ml})$ and $640 \mu \mathrm{mol} / 1(7.2 \mathrm{mg} / 100 \mathrm{ml})$ respectively) before and during treatment with $1-\alpha-\mathrm{OHD}_{3} 2 \mu \mathrm{g} /$ daily by mouth (see figure). Considerable increases in calcium retention during the first four days of treatment in case 1 , and after 18 months in case 2 (a renal dwarf who ate little calcium), were unaccompanied by significant changes in magnesium balance.
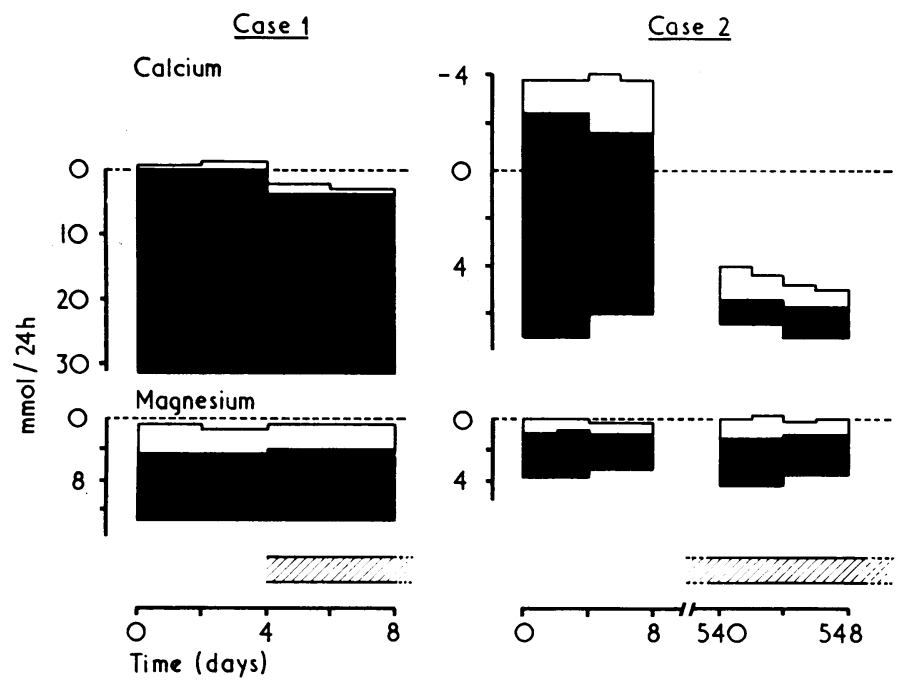

Urinary (white areas) and faecal (black areas) excretion of calcium and magnesium in cases 1 and 2 before and during treatment with $1-\alpha-\mathrm{OHD}_{3}$ (hatched areas). Case 2 was restudied after 18 months of continuous treatment.

Conversion: SI to traditional units-Calcium: $1 \mathrm{mmol} / 24 \mathrm{~h} \approx 40 \mathrm{mg} / 24 \mathrm{~h}$. Magnesium: $1 \mathrm{mmol} / 24 \mathrm{~h} \approx 24.3 \mathrm{mg} / 24 \mathrm{~h}$.

In 13 other patients with chronic renal failure, nine of whom were being treated with haemodialysis, there was no significant difference between the mean predialysis plasma magnesium concentrations before (mean $1 \cdot 14 \pm \mathrm{SE}$ of mean $0.06 \mathrm{mmol} / \mathrm{l} ; 2.77 \pm 0.15 \mathrm{mg} / 100 \mathrm{ml}$ ) and after nine months' treatment with $1-\alpha-\mathrm{OHD}_{3}(1.23 \pm 0.04 \mathrm{mmol} / 1 ; 2.99 \pm 0.97 \mathrm{mg} / 100 \mathrm{ml})$. During long-term treatment hypercalcaemia occurred in 10 of these patients (range $2 \cdot 65-3.38 \mathrm{mmol} / 1 ; 10.60-13.52 \mathrm{mg} / 100 \mathrm{ml}$ ) but there was no significant change in the mean plasma magnesium concentration $(1.32 \pm 0.08 \mathrm{mmol} / 1$; $3.21 \pm 0.19 \mathrm{mg} / 100 \mathrm{ml}$ ). In some patients, however, the plasma magnesium concentration increased by up to $0.53 \mathrm{mmol} / 1(1.28 \mathrm{mg} / 100 \mathrm{ml})$ during hypercalcaemia, but no measurements of possible variations in the dietary intake of magnesium were made and the increases did not correlate with those of calcium.

\section{Comment}

Changes in intestinal absorption of magnesium might be expected to resemble those of calcium, but several observations suggest that this may not be so. Firstly, animal studies and our observations in uraemic patients suggest that magnesium absorption is not increased by doses of $1-\alpha-\mathrm{OHD}_{3}$ sufficient to increase greatly the retention of calcium, although vitamin-D-induced magnesium absorption may become apparent only when the magnesium intake is increased. Secondly, like others, ${ }^{34}$ we have observed no consistent changes in plasma magnesium after long-term treatment with $1-\alpha-\mathrm{OHD}_{3}$, even after accidental overdose. Finally, in chronic renal failure plasma magnesium concentrations rise when the dietary intake of magnesium is moderately increased, ${ }^{5}$ whereas plasma calcium is affected only by large increases in oral calcium intake.

Our evidence suggests that $1-\alpha-\mathrm{OHD}_{3}$ may have little effect on magnesium absorption in chronic renal failure and that increased plasma magnesium concentrations associated with the administration of $1-\alpha-\mathrm{OHD}_{3}{ }^{1}$ may independently reflect changes in the dietary intake of magnesium. This conclusion cannot necessarily be extended to other vitamin $\mathrm{D}$ metabolites or to patients without renal failure.

We thank Leo Laboratories for supplying $1-\alpha-\mathrm{OHD}_{3}$, and the Wellcome Trust and National Fund for Research into Crippling Diseases for financial support.

${ }^{1}$ Sorensen, E, et al, British Medical fournal, 1976, 2, 215.

2 Smith, R, et al, Quarterly fournal of Medicine, 1973, 42, 235.

3 Tougaard, L, et al, Lancet, 1976, 1, 1044.

Nielsen, S P, et al, Vitamin D and Problems Related to Uraemic Bone Disease, $\mathrm{p}$ 623. Berlin, De Gruyter, 1975.

${ }^{5}$ Randall, R E, et al, Annals of Internal Medicine, 1964, 61, 73.

(Accepted 8 October 1976)

Metabolic Unit, Nuffield Orthopaedic Centre, Oxford

J A KANIS, MRCP, Wellcome senior clinical research fellow

R SMITH, PHD, FRCP, first assistant and honorary consultant physician R J WALTON, MRCP, Goodger scholar

M BARTLETT, technician

\section{Acute ileus in myxoedema}

Acute ileus mimicking a surgical emergency is a rare complication of severe hypothyroidism. Bastenie ${ }^{1}$ concluded that it was caused by myxoedematous deposits separating muscle fibres in the bowel wall from their ganglia. We report a typical case, which throws new light on the pathology of this condition.

\section{Case report}

A 68-year-old woman was admitted with a history of increasing confusion. She was myxoedematous, and the abdomen was grossly distended, with scant bowel sounds. Her temperature was $35.4^{\circ} \mathrm{C}$ and blood pressure $60 / 40 \mathrm{~mm} \mathrm{Hg}$. Myxoedematous precoma with concurrent bowel obstruction was diagnosed. Treatment with triiodothyronine $200 \mu \mathrm{g} 8$ hourly for 48 hours and thyroxine $0.25 \mathrm{mg} /$ day was started, and the obstruction was treated conservatively with fluid and electrolyte replacement. On admission potassium concentration was $2.4 \mathrm{mmol}(\mathrm{mEq}) / 1$, protein-bound iodine $130 \mathrm{nmol} / 1(1.6 \mu \mathrm{g} / 100 \mathrm{ml})$, and thyroxine $10 \mathrm{nmol} / 1(0.8 \mu \mathrm{g} / 100 \mathrm{ml})$. The hypokalaemia was attributed to preadmission diuretic treatment. A folate defficiency megaloblastic anaemia (haemoglobin $5.4 \mathrm{~g} / \mathrm{dl}$; folate $1.0 \mathrm{mg} / \mathrm{l}$ ), which was thought to be dietary, was treated with vitamin $\mathrm{B}_{12}$ and folate. Blood pressure and temperature quickly returned to normal. Abdominal radiographs indicated a paralytic type of ileus, and conservative treatment was continued. After 10 days the hypothyroidism was much improved, and the ileus had become the dominant problem. Potassium values were consistently normal at this stage, and although the initial hypokalaemia may have aggravated the ileus, it became clear that the likely cause of the continuing ileus was myxoedema. The abdominal signs showed no improvement, and the patient died after 20 days.

Pathological findings-At necropsy the thyroid was shown to be replaced by fibrous tissue. The heart was normal and there was moderate pulmonary oedema. The colon was slightly dilated but otherwise macroscopically normal. Paraffin sections of mucosa, muscle coats, and the myenteric plexus were normal, and special stains showed no mucopolysaccharide deposits in the bowel wall. Frozen sections through the myenteric plexus stained with silver showed a few round clear areas, devoid of stainable material, and the neurones and processes were distorted around them. Some axons were grossly abnormal, showing ellipsoids, axon swellings, and fragmentation. These changes were present in the plexus itself, but more prominently in the trunks entering the bowel from outside.

\section{Comment}

Previous reports of acute ileus in myxoedema emphasise the inadvisability of surgical intervention. A broad spectrum of reduced 
gastrointestinal activity in myxoedema-from chronic constipation to the most severe ileus-has been reported. The milder forms are reversible with thyroid hormone replacement, but more severely affected patients die of other complications of hypothyroidism before treatment has had time to be effective. Only one other report ${ }^{2}$ has attributed death to the ileus.

The pathological findings in our case suggest that the ileus was due to a peripheral neuropathy affecting the gut. Myxoedema is known to be associated with a polyneuropathy, ${ }^{3}$ the changes in peripheral nerves suggesting that Schwann cell disease, possibly caused by mucopolysaccharide deposition, is partly or wholly responsible for the disorder. Although no mucopolysacchardie was found in this case, Byrom ${ }^{4}$ showed that it disappears within days of thyroid hormone administration. The axons, however, were abnormal, showing a severe autonomic neuropathy affecting mainly the extrinsic nerves in the colon, but also suggesting intrinsic nerve involvement.

That peripheral neuropathy can affect the alimentary canal as well as the limbs is well recognised, as in diabetes mellitus. ${ }^{5}$ Anatomical changes in bowel innervation are in fact common, but clinical symptoms are rare, probably because slight changes in the nerve supply to the limbs are enough to produce parasthesiae, but to produce a megacolon damage has to be almost complete. The pathological changes in this case suggest that the ileus might have been reversible with thyroid hormone replacement had the patient survived.

1 Bastenie, P A, Lancet, 1946, 1, 413.

2 Chadha, J S, Ashby, D W, and Cowan, W K, British Medical fournal, $1969,3,398$.

${ }^{3}$ Dyck, P J, and Lambert, E H, fournal of Neuropathology and Experimental Neurology, 1970, 29, 631

${ }^{4}$ Byrom, F B, Clinical Science, 1933-34, 1, 273.

5 Smith, B, fournal of Neurology, Neurosurgery, and Psychiatry, 1974, 37, 1151.

(Accepted 19 October 1976)

Department of Diagnostic Radiology, King's College Hospital, London SE5

IRVING WELLS, MB, MRCP, registrar

Department of Pathology, St Bartholomew's Hospital, London EC1 BARBARA SMITH, MD, FRCS, senior lecturer

St Richard's Hospital, Chichester, Sussex

MICHAEL HINTON, BM, MRCP, consultant physician

\section{Klinefelter's syndrome with hypogonadotrophic hypogonadism}

Patients with Klinefelter's syndrome have raised circulating follicle stimulating hormone (FSH) levels. Luteinising hormone ( $\mathrm{LH})$ levels are usually increased also, but they may be within the normal range when the testosterone secretion rate approaches normal. ${ }^{1}$ We describe here a patient who showed the clinical features of Klinefelter's syndrome associated with low testosterone levels, undetectable LH, and FSH levels that were not raised. When the patient's age is considered the FSH levels were actually below normal. ${ }^{2}$

\section{Case report}

A 70-year-old man with an eight-year history of diabetes mellitus presented with gangrene of the left foot. Conservative treatment was unsuccessful and a below-knee amputation was subsequently performed. On examination he was mildy obese and appeared hypogonadal with a high-pitched voice, a eunuchoidal habitus (span $187 \mathrm{~cm}$, height $174 \mathrm{~cm}$, and upper:lower segment ratio of $0 \cdot 8: 1$ ), smooth skin, and fine, soft, facial hair. There was bilateral (2. $2 \mathrm{~cm}$ ) gynaecomastia, body hair was sparse, both testes were soft $(1 \times 0.5 \mathrm{~cm}$ ), and his penis was $5 \mathrm{~cm}$ in length (stretched). Visual fields and sense of smell were unimpaired. There were signs of peripheral vascular disease in the right leg but no carotid bruits were present. The fundi were not seen owing to bilateral cataracts. On direct questioning he said that he had developed only a small amount of pubic and axillary hair in his teenage years and that he had never shaved. There was no family history of endocrinopathy.

A clinical diagnosis of Klinefelter's syndrome was confirmed by a positive buccal smear and a karyotype of $47, \mathrm{XXY}$ from peripheral blood. The serum testosterone level was $1.04 \mathrm{nmol} 1(0.29 \mathrm{ng} / \mathrm{ml})$, serum $\mathrm{LH}<25 \mu \mathrm{g}$ LER907/1, and serum FSH $230 \mu \mathrm{g}$ LER-907 1. A luteinising hormone-releasing hormone (LHRH) test showed normal FSH and LH responses (see table). A thyrotrophin-releasing hormone test (400 $\mu \mathrm{g}$ intravenously) resulted in normal thyrotrophin and prolactin responses. Serum cortisol was $640 \mathrm{nmol} /$ $(23.2 \mu \mathrm{g} / 100 \mathrm{ml}$ ) (normal 200-660 nmol/1 (7.0-23.9 $\mu \mathrm{g} / 100 \mathrm{ml}$ )). Radiographs of the sella turcica were normal, as was a brain scan.

No androgen replacement therapy was considered to be warranted, and after he recovered from the amputation the patient was discharged from hospital.

\section{Comment}

There are only two other reports describing patients with chromatinpositive Klinefelter's syndrome associated with low gonadotrophin levels. The first describes a 74-year-old man with XY/XXY mosaicism who had low circulating LH and testosterone levels. No comment was made about the FSH levels. ${ }^{3}$ The second report describes an 18-yearold man with $\mathrm{XO} / \mathrm{XY} / \mathrm{XXY}$ mosaicism in whom the circulating FSH levels were undetectable. Serum testosterone levels were in the low normal range and serum LH levels varied between normal and high values. ${ }^{4}$

The cause of the bihormonal gonadotrophin deficiency in our patient is obscure and a congenital abnormality cannot be excluded. A pituitary tumour seems unlikely in view of the normal skull radiographs, visual fields, and provocative test results. Diabetes mellitus, which presumably predisposed to the peripheral vascular disease, could theoretically have affected the microvasculature of the hypothalamicpituitary axis, but it is unlikely that this would have resulted in a "selective" gonadotrophin deficiency (although growth hormone reserve was not tested), particularly as the responses to LHRH were normal. Possibly our patient's condition represents a variant of Klinefelter's syndrome with a reduction in the release of $\mathrm{LH}$ and FSH occurring secondary to prolonged hypersecretion, as suggested by Rabinowitz et al in their case report mentioned above. ${ }^{4}$

JNC is an overseas fellow of the Royal Australasian College of Physicians. The support of the Postgraduate Medical Foundation is gratefully acknowledged.

${ }^{1}$ Williams, R H (editor), Textbook of Endocrinology, 5th edn, p 335. Philadelphia, Saunders, 1974.

2 Stearns, E L, et al, American fournal of Medicine, 1974, 57, 761.

${ }^{3}$ Shirai, M, Matsuda, S, and Jitsukawa, S, Tohoku fournal of Experimental Medicine, 1974, 114, 131.

${ }^{4}$ Rabinowitz, D, et al, American fournal of Medicine, 1975, 59, 584.

(Accepted 4 October 1976)

Section of Endocrinology and Metabolism, Department of

Physiology, University of Manitoba, Winnipeg, Manitoba, Canada J N CARTER, MD, FRACP, fellow in endocrinology

D G H WISEMAN, MD, FRCP(C), senior resident in endocrinology

H B LEE, MD, senior resident in endocrinology

Responses to LHRH test (100 $\mu \mathrm{g}$ given intravenously)

\begin{tabular}{|c|c|c|c|c|c|c|c|c|c|c|}
\hline Time (min): & -30 & 0 & 15 & 30 & 45 & 60 & 90 & 120 & 180 & $\begin{array}{l}\text { Normal } \\
\text { values* }\end{array}$ \\
\hline $\begin{array}{l}\text { FSH ( } \mu \text { g LER-907/1) } \\
\text { LH }(\mu \mathrm{g} \text { LER-907/1) } \\
\text { Testosterone }(\mathrm{nmol} / \mathrm{l})\end{array}$ & $\begin{array}{l}230 \\
<25 \\
1 \cdot 04\end{array}$ & $\begin{array}{l}200 \\
<25\end{array}$ & $\begin{array}{r}310 \\
53\end{array}$ & $\begin{array}{r}380 \\
79\end{array}$ & $\begin{array}{l}430 \\
101\end{array}$ & $\begin{array}{l}470 \\
119\end{array}$ & $\begin{array}{l}510 \\
170\end{array}$ & $\begin{array}{l}670 \\
190\end{array}$ & $\begin{array}{l}870 \\
210 \\
0.73\end{array}$ & $\begin{aligned} 469 & \pm 55 \\
97 & \pm 66 \\
14 \cdot 4 & \pm 6 \cdot 0\end{aligned}$ \\
\hline
\end{tabular}

*Normal basal values ( $\pm S D$ ) for men aged 70-79 years. ${ }^{2}$

Conversion: SI to traditional units-Testosterone: $1 \mathrm{nmol} / 1 \approx 0.288 \mathrm{ng} / \mathrm{ml}$. 